\title{
The Influence of Human Capital and Financial Assets on Rural Family Entrepreneurship
}

\author{
Wei Li, Ping $\mathrm{Wu}^{*}$ \\ College of Economics \\ Sichuan Agricultural University \\ Chengdu, China \\ 565103327@qq.com, 1547828092@qq.com*
}

\begin{abstract}
In this paper, we use the Probit and Tobit models to analyze the influence of human capital and financial assets on rural family entrepreneurship through the analysis of data from China Household Financial Survey (CHFS) in 2013. The results show that the accumulation of human capital and the increase of financial assets will significantly increase the probability of family entrepreneurship, but will reduce the probability of family choosing to engage in agricultural production and management activities. In terms of entrepreneurial performance, the increase of educational years, the improvement of health level and the growth of financial assets can have a significant positive effect on entrepreneurial performance. Besides, family entrepreneurship in rural areas is also affected by family factors and regional differences. Based on this, we put forward some policy suggestions, such as strengthening the cultivation of rural human capital and further improving the rural financial market system.
\end{abstract}

Keywords-Human capital; Financial assets; Rural families; Entrepreneurship

\section{INTRODUCTION}

As the new momentum and engine of economic development under the background of the new normal economy, entrepreneurship has become a hot topic in recent years. As an important part of "mass entrepreneurship", rural family entrepreneurship plays an important role in absorbing rural labor transfer, improving employment, increasing peasant income and promoting the strategy of "rural revitalization". The report of the 19th National Congress of the CPC also pointed out that we should promote the integration of rural primary, secondary and tertiary industries, support and encourage peasants to find jobs and start undertakings, and broaden the channels for increasing income.

At present, the research on rural household entrepreneurship has paid more attention to capital acquisition, risk preference, work experience and so on, but few papers have paid attention to the comprehensive impact of human capital and financial assets on rural household entrepreneurship In fact, "human" and "money" are the most important factors of entrepreneurship.The essence of entrepreneurship is the combination of entrepreneurs'human resources, material materials and so on to achieve greater value. Therefore, this paper comprehensively studies the impact of human capital and financial assets on rural household entrepreneurship, and provides a reference for the formulation of incentive policies for entrepreneurship in China.

\section{LITERATURE REVIEW}

On the impact of human capital on entrepreneurship, Schulyz (1961) argues that human capital includes knowledge, skills and health, and entrepreneurs can increase their ability to distribute market elements through accumulation of human capital [1]. Evans and Jovanovic (1989) found that when entrepreneurs ability is stronger, the material restrictions of entrepreneurship are correspondingly weaker[2]. Anwar and Chan (2016) through a comparative study of two Indonesian villages, they found that training and upgrading skills will enhance the willingness of migrant workers to return home and start their own businesses [3]. Most domestic scholars also get similar conclusions. For example, Zhao Haoxing et al (2013) through the analysis of 708 samples from Zhejiang and other provinces, it shows that the human capital of rural entrepreneurs has a significant role in improving entrepreneurial performance [4]. Zhou Yang and Liu Xuejin (2017) found that vocabulary memory and mathematical ability had significant positive effects on entrepreneurial behavior [5].Qi Diming and Liu Yuxia (2018) used policy acquisition as an intermediary variable to verify the positive impact of human capital on entrepreneurial performance of migrant workers [6].

In comparison, there are few studies directly discussing the impact of financial assets on entrepreneurship, and most of the existing literature is from the perspective of financing. For example, Charles and Hurst (2003) believes that family wealth level will affect family entrepreneurial decision-making and preferences, the higher the wealth level of family, the stronger of risk-taking ability and the greater the entrepreneurial probability [7]. Djankov (2006) also demonstrates that financing resources and institutional guarantees are very important factors for entrepreneurship [8]. Ma Guangrong and Yang Enyan (2011) pointed out that the initial funds needed by farmers to start a business largely come from the borrowing of relatives and friends, and informal finance supports farmers to start a business [9]. Su Lanlan (2016) also believe that the expansion of financial scale has a significant positive impact on farmers'entrepreneurial activities [10]. Li Yiwen and Zhang Bing (2016) found that informal finance affected rural household entrepreneurship decision-making by easing supplyoriented and demand-oriented credit constraints, and promoted their discovery of entrepreneurial opportunities and resources [11]. Liu Xinzhi et al (2017) demonstrated the importance of financial support for rural family entrepreneurship from the perspective of spatial differences, and the family 
entrepreneurial in areas where financial support is effective are more active [12].

In a word, scholars at home and abroad have done a lot of useful exploration on rural family entrepreneurship, but there are also areas that need further study. The main differences between this paper and the existing literature are as follows: First, we comprehensively discusses the influence of human capital, financial assets and rural family entrepreneurship for the first time. Secondly, on the basis of relevant research, human capital is measured by educational level and health level, financial assets are measured by household financial assets and loans, and entrepreneurial activities are measured by entrepreneurial decision-making and entrepreneurial performance. Thirdly, different from the regional data used in previous studies,we use the Chinese Household Financial Survey (Chfs) survey data, which has a large sample size and covers the whole country, and can more accurately reflect the relationship among the three.

\section{SAMPLE SELECTION AND RESEARCH DESIGN}

\section{A. Data Source Description}

We use data from the China Household Financial Survey and Research Center of Southwest University of Finance and Economics (CHFS) in 2013. In order to maintain the accuracy and comparability of the data, we matche the family sample with the individual sample according to the coding, and eliminates the missing value or obvious error value of the important variables in the original data, and converts the unit into a unified one. Because we focuse on the entrepreneurial behavior of farmers, after considering the differences and reality, we choose the urban and rural attributes of household registration as the criteria for classification, only retaining the rural sample. The sample size is 14064 .

\section{B. Variable Selection}

The dependent variable is the rural family entrepreneurship, and it involves two aspects: entrepreneurial decision-making and entrepreneurial performance. The question about entrepreneurship in CHFS questionnaire is "whether your family is engaged in individual small handicraft business and enterprise management". Referring to the methods of most scholars, we use the answer to this question "yes" or "no" as the criterion for entrepreneurship to construct a virtual variable, entrepreneurship is 1 , otherwise $0(\mathrm{Y})$. At the same time, this article uses "whether to engage in agricultural production and management" (Y1) as an agricultural entrepreneurship to make a comparison. As for entrepreneurial performance,we choose the actual value of "how much is the operating income of these projects" (income/income1) to measure.

With regard to the core explanatory variable human capital, we evaluate it by "years of education" (edu) and "health level" (health) and sets up fictitious variables according to actual answers. Financial assets are measured by the real value of "external financing" (Wfinance) obtained from all household credit activities and "financial assets owned by household" (Zfinance).
In addition, in order to make the results more accurate, we add individual characteristics variables including gender (sex), age (age), risk preference (risk), number of siblings (other), family size (family) as control variables. The regional feature variables are set as dummy variables (area).

\section{Model Setting}

Because the rural household entrepreneurial decisionmaking are binary choice variables, we set the following binary Probit model:

$$
\begin{gathered}
\mathrm{Y}_{i}=\alpha_{1} \text { edu }_{i}+\alpha_{2} \text { health }_{i}+\alpha_{3} \text { Zfinance }_{i} \\
+\alpha_{4} \text { Wfinance }_{i}+\sum \text { Control }+\mu_{i}
\end{gathered}
$$

Among them, $\mathrm{Y}$ is a variable for rural family entrepreneurship. When family starts business, $Y=1$.Edu, health, Zfinance and Wfinance represent the core explanatory variables:education, health, external financing and self-owned financial assets respectively, and $\alpha_{1}, \alpha_{2}, \alpha_{3}$ and $\alpha_{4}$ represent their coefficients respectively. Control represents the control variable group. The $\mu_{i}$ is the error term and obeys the normal distribution.

Since the household entrepreneurial income without entrepreneurship is 0 , entrepreneurial income is a continuous truncated variable, so choose Tobit model to analyze, when $\mathrm{Y}_{i}=1$, its expression is as follows:

$$
\begin{gathered}
\text { Income }_{i}^{*}=\alpha_{1} \text { edu }_{i}+\alpha_{2} \text { health }_{i}+\alpha_{3} \text { Zfinance }_{i}+ \\
\alpha_{4} \text { Wfinance }_{i}+\sum \text { Control }+\mu_{i}
\end{gathered}
$$

Among them, Income represents family entrepreneurship performance.

\section{EMPIRICAL RESULTS AND ANALYSIS}

\section{A. Descriptive Statistics}

The results of descriptive statistics are shown in Table I. Only $15.27 \%$ of the households choose industrial and commercial entrepreneurship, while more than $66.21 \%$ of the households are still engaged in agricultural production and management. But from entrepreneurial performance, industrial and commercial entrepreneurial income is much higher than that of agricultural production and operation. As far as education is concerned, the average length of schooling for rural residents is only 7.61 years. That is to say, most of them only have junior middle school education, and the level of rural education is still low. This also shows that rural credit is relatively active, but this activity is more likely to be dominated by informal finance, rural formal financial system is still weak. 
TABLE I. DESCRIPTIVE STATISTICS OF MAJOR VARIABLES

\begin{tabular}{|l|l|l|l|l|}
\hline variable & \multicolumn{1}{c|}{ Mean } & \multicolumn{1}{c|}{ Std } & \multicolumn{1}{c|}{ Min } & \multicolumn{1}{c|}{ max } \\
\hline Y & 0.1527304 & 0.3597402 & 0 & 1 \\
\hline Y1 & 0.662116 & 0.4730056 & 0 & 1 \\
\hline income & 2.069418 & 17.91674 & 0 & 500 \\
\hline income1 & 0.6646133 & 1.655789 & 0 & 40 \\
\hline edu & 7.606924 & 4.004246 & 0 & 22 \\
\hline health & 3.291893 & 1.000077 & 1 & 5 \\
\hline Zfinance & 1.429454 & 6.911422 & 0 & 308 \\
\hline Wfinance & 1.756873 & 9.959625 & 0 & 520 \\
\hline sex & 0.5036263 & 0.5000046 & 0 & 1 \\
\hline risk & 2.116513 & 1.234819 & 1 & 5 \\
\hline other & 3.417002 & 2.020244 & 0 & 16 \\
\hline age & 44.49929 & 17.40815 & 18 & 80 \\
\hline family & 4.454849 & 1.75011 & 1 & 18 \\
\hline
\end{tabular}

\section{B. Human Capital, Financial Assets and Entrepreneurial Decision-making}

Since (1) has nonlinear characteristics, the average marginal effect is given in Table II. From the results, we can see that for rural households to start business, the respondents'educational years, health level, household financial assets and external financing have a significant positive impact. Specifically, the probability of choosing to start an undertaking increases 0.7 and 2.2 percentage points respectively when the educational level and health status of farmers increase one unit. Similar to the results of theoretical research, good physical fitness is the basis for high-intensity entrepreneurial activities, and generally higher-educated people have more knowledge and greater ability to control business opportunities. From the perspective of financial assets, the marginal effect of household financial assets and external financial assets on farmers'choice of entrepreneurship is 0.010 and 0.003 respectively.This result can also be interpreted that entrepreneurship as venture investment must have sufficient capital, the more financial assets, the more investment projects can be carried out.And the ability to avoid risks is also stronger.

In comparison,only health level has a positive impact on the choice of agricultural production and operation, while education level and household financial assets have a negative impact on it. Specifically, the probability of engaging in agricultural production and operation decreased by 1.2 percentage points when the educational level of farmers increase one unit. It decreased 1.7 and 0.2 percentage points respectively when the own financial assets and external financing increase one unit. In fact, agricultural production and management itself has a certain weakness, compared with industrial and commercial activities, the benefits of them are not high. From the perspective of rational people, in order to obtain high returns, farmers will naturally choose to engage in industrial and commercial entrepreneurial activities.

In addition, The influence of risk preference varies greatly. People with stronger risk tolerance are more likely to choose industrial and commercial entrepreneurship. The marginal effect of risk preference on entrepreneurship is 0.017 , and the marginal effect on agricultural production and operation is 0.009 . In terms of age, the probability of choosing industrial and commercial entrepreneurship will decrease with age. From the perspective of household population, the size of household population will have a positive impact on industrial and commercial entrepreneurship and agricultural production and operation.Besides, there are differences between regions. There are more family choose industrial and commercial activities in east, while there are more family choose agricultural production and operation activities in west.

TABLE II. ENTREPRENEURIAL DECISION-MAKING AND PERFORMANCE

\begin{tabular}{|c|c|c|c|c|}
\hline variable & $\mathbf{Y}$ & Y1 & Income & Income1 \\
\hline edu & $\begin{array}{l}0.00688 * * * \\
(0.0014)\end{array}$ & $\begin{array}{l}-0.01259 * * * \\
(0.0017)\end{array}$ & $\begin{array}{l}0.24858 * * * \\
(0.0552)\end{array}$ & $\begin{array}{l}- \\
0.00721 * * \\
(0.0035)\end{array}$ \\
\hline health & $\begin{array}{l}0.02270 * * * \\
(0.0045)\end{array}$ & $\begin{array}{l}0.00725 * * * \\
(0.0055)\end{array}$ & $\begin{array}{l}0.80573 * * * \\
(0.1791)\end{array}$ & $\begin{array}{l}0.02929 * * \\
* \\
(0.1139)\end{array}$ \\
\hline Zfinance & $\begin{array}{l}0.00970 * * * \\
(0.0094)\end{array}$ & $\begin{array}{l}-0.00681 * * * \\
(0.0011)\end{array}$ & $\begin{array}{l}0.13028 * * * \\
(0.0155)\end{array}$ & $\begin{array}{l}- \\
.00299 * * * \\
(0.021)\end{array}$ \\
\hline $\begin{array}{l}\text { Wfinanc } \\
\text { e }\end{array}$ & $\begin{array}{l}0.00312 * * * \\
(0.0058)\end{array}$ & $\begin{array}{l}-0.00214 * * * \\
(0.1067)\end{array}$ & $\begin{array}{l}0.16578 * * * \\
(0.0113)\end{array}$ & $\begin{array}{l}0.00801 \\
* * * \\
(0.0114)\end{array}$ \\
\hline $\operatorname{sex}$ & $\begin{array}{l}-0.00941 \\
(0.0086)\end{array}$ & $\begin{array}{l}0.02114 * * \\
(0.1067)\end{array}$ & $\begin{array}{l}-0.11987 \\
(0.3405)\end{array}$ & $\begin{array}{l}- \\
0.04755^{* *} \\
(0.2293)\end{array}$ \\
\hline risk & $\begin{array}{l}0.01666^{* * * *} \\
(0.0034)\end{array}$ & $\begin{array}{l}-0.00862 * * \\
(0.1067)\end{array}$ & $\begin{array}{l}0.66571 * * * \\
(0.1349)\end{array}$ & $\begin{array}{l}0.02140 * * \\
(0.0092)\end{array}$ \\
\hline other & $\begin{array}{l}-0.00213 \\
(0.0021)\end{array}$ & $\begin{array}{l}0.00622 * * \\
(0.0026)\end{array}$ & $\begin{array}{l}-0.04683 \\
(0.0855)\end{array}$ & $\begin{array}{l}0.02764 * * \\
(0.0055)\end{array}$ \\
\hline age & $\begin{array}{l}-0.00142 * * * \\
(0.0004)\end{array}$ & $\begin{array}{l}0.00557 * * * \\
(0.0048)\end{array}$ & $\begin{array}{l}-0.06578^{* * *} \\
(0.0161)\end{array}$ & $\begin{array}{l}0.004743 * \\
* * \\
(0.0001)\end{array}$ \\
\hline family & $\begin{array}{l}0.01135 * * * \\
(0.0026)\end{array}$ & $\begin{array}{l}0.02709 * * * \\
(0.0033)\end{array}$ & $\begin{array}{l}0.31827 * * * \\
(0.1036)\end{array}$ & $\begin{array}{l}0.04522 * * \\
* \\
(0.0679)\end{array}$ \\
\hline area & $\begin{array}{l}-0.0221 * * * \\
(0.0057)\end{array}$ & $\begin{array}{l}0.13506 * * * \\
(0.0066)\end{array}$ & $\begin{array}{l}-0.94565 * * * \\
(0.2266)\end{array}$ & $\begin{array}{l}0.11555^{* *} \\
* \\
(0.1464)\end{array}$ \\
\hline
\end{tabular}

${ }^{\text {a. }}$ Note: $*, * *, * * *$ mean that respectively denying the null hypothesis at the significant level of $1 \%, 5 \%$ and $10 \%$

\section{Human Capital, Financial Assets and Entrepreneurial Performance}

From the results of (2), we can see that human capital variables and financial assets variables have significant positive effects on business start-up performance. The growth of educational years and health level will significantly increase entrepreneurship income, and the marginal contribution is 0.249 and 0.806 respectively. Likewise, improved health level will improve the management and control of entrepreneurship projects, thereby increasing incomes. The marginal contribution of private assets and external financing to entrepreneurship performance also reached 0.130 and 0.166 respectively. It is not difficult to understand that when the financial assets of family are sufficient, it will be easier to expand the scale, so as to obtain more income. At the same 
time, the risk of insufficient funds will be reduced, reducing the loss that may be found.

For the performance of agricultural production and operation, education level, health level and external financing also have a significant positive effect on it. Agricultural management performance increased by $1.7,2.9$ and 0.8 percentage points respectively when education level, health level and external financing increase one unit. However, the effect of household financial assets on agricultural production performance is not significant, farmers will not choose to liquidate household financial assets to support agricultural production, and agricultural production investment scale also is relatively small.

In terms of other control variables, women are more likely to bring more benefits whether they are engaged in industrial and commercial undertakings or agricultural undertakings. From the perspective of risk preference, the marginal contribution of risk preference to business entrepreneurial performance and agricultural entrepreneurial performance is 0.266 and 0.021 respectively. It is likely that people who take higher risks are more likely to control the opportunities. Respondents'age will have a negative marginal effect on household business performance, and a positive effect on agricultural production performance. Besides, family size can also positively affect entrepreneurial performance. Regional differences also exist, in east,farmers engaged in industrial and commercial entrepreneurship usually get higher performance, while it is just the opposite in west.

\section{SUMMARY}

We empirically analyze the impact of human capital and financial assets on the entrepreneurial activities of rural households. The results show that from the perspective of entrepreneurial decision-making, the accumulation of human capital and the increase of financial assets will significantly increase the probability of farmers choosing industrial and commercial entrepreneurship. On the contrary, households with higher educational years and more financial assets were less likely to choose agricultural production and operation. From the perspective of entrepreneurship performance, human capital and financial assets will have a positive effect on both industrial and commercial entrepreneurship and agricultural production and operation, which confirms the argument that "human" and "money" are very important for entrepreneurship.

\section{SUGGESTION}

This study has important policy implications. First, in the current situation of relatively weak human resources in rural areas, we should continue to strengthen the cultivation of human capital in rural areas. We should formulate, improve and strictly implement relevant education and training policies, carry out training for new type of professional farmers according to local conditions, explore and establish a certification mechanism for agricultural professional managers, and guide rural labor employment and entrepreneurship. Second, we will accelerate the construction and improvement of the rural financial system to provide financial support for rural residents to start a business. On the one hand, we should continue to guide formal financial institutions to provide more resources and services in rural areas, and establish relevant safeguards and subsidies system.On the other hand, relevant laws and regulations should be established to provide a basis for informal financial institutions to enter the financial market legally.

\section{REFERENCES}

[1] T.W. Schultz, "Investment in Human Capital," Economic Journal, vol. 82(326), pp. 787, 1961.

[2] D.S. Evans and B. Jovanovic, "An Estimated Model of Entrepreneurial Choice under Liquidity Constraints," Journal of Political Economy, vol. 97(4), pp. 808-827, 1989.

[3] R.P. Anwar and C. Chan, "Contrasting Return Migrant Entrepreneurship Experiences in Javanese Villages," International Migration, vol. 54(4), pp. n/a-n/a, 2016.

[4] H.X. Zhao and Q.W. Zhang, "Study on the Relationship between Human Capital of Migrant Workers Returning to Home and the Growth of Entrepreneurial Enterprises: Based on the Empirical Analysis of Jiangxi and Guizhou," East China Economic Management, vol. 2013 (1), pp. 130-133.

[5] Y. Zhou and X.J. Liu, "Cognitive Ability and Family Entrepreneurship: An Empirical Analysis Based on Data from China Family Tracking Survey (CFPS)," Economic Dynamics, vol. 2017 (2), pp. 66-75.

[6] D.M. Qi and Y.X. Liu, "Human Capital, Policy Acquisition and Entrepreneurial Performance of Returned Migrant Workers: A Survey Based on Zhejiang," Zhejiang Journal, vol. 2018 (2).

[7] K.K. Charles and E. Hurst, "The Correlation of Wealth across Generations," Journal of Political Economy, vol. 111(6), pp. 1155-1182, 2003.

[8] S. Djankov, W. Bank, and Y. Qian, "Entrepreneurship in Development: First Results from China and Russia," aea, 2006.

[9] G.R. Ma and E.Y. Yang, "Social network, informal finance and entrepreneurship," Economic research, vol. 2011 (3), 83-94.

[10] L.L. Su, Y.L. Peng, and R. Kong, "Empirical Study on the Impact of Venture Capital on the Entrepreneurial Performance of Farmers--Based on the Survey of Farmers in Shaanxi, Gansu, Henan and Shandong," Journal of Agricultural and Forestry Economics and Management, vol. 15 (2), pp. 169-178, 2016.

[11] Y.W. Li and B. Zhang, "Informal Finance on rural household entrepreneurship,” Economic Science, vol. 2016 (02), 93-105.

[12] X.Z. Liu, Y.S. Liu, and Y.S. Liu, "The Impact of Financial Support on Rural Households'Entrepreneurship and Its Spatial Difference Analysis-Based on CFPS2010 14 Data," Macroeconomic Research, vol. 2017 (11), pp. 139-149. 